\title{
Jurnal Publisitas
}

Vol. 1, No. 1, Oktober 2019

Website: http://ejurnal.stisipolcandradimuka.ac.id/index.php/JurnalPublisitas

ISSN 2252-4150

\section{OPEN AIR CINEMA SEBAGAI RUANG KOMUNIKASI}

\author{
Budi Dwi Arifianto ${ }^{1}$, Zein Mufarrih Muktaf ${ }^{2}$ \\ ${ }^{1}$ Universitas Muhammadiyah Yogyakarta, Indonesia, buditobon@gmail.com \\ ${ }^{2}$ Universitas Muhammadiyah Yogyakarta, Indonesia, zeinmufarrih@gmail.com \\ DOI: $10.17605 / O S F . I O / 4 T G J A$
}

\begin{abstract}
Abstrak
Open air cinema atau sering disebut layar tancap adalah sebuah gaya eksebisi film yang memutar filmnya di ruang terbuka. Desa Sumber yang terletak di Magelang Jawa Tengah tengah menginisasi diri menjadi desa wisata kreatif. Tahap awal yang tengah digagas adalah mengeksplorasi potensi desa sebagai komoditas yang nantinya ditawarkan sebagai sebuah desa wisata kreatif. Film dianggap sebagai solusi untuk menjawab permasalahan tersebut. Film sebagai produk seni dipilih sebagai medium pemberdayaan manusia, khususnya medium mengembangkan potensi desa. Tujuan dari penelitian ini adalah untuk mengetahui bagaimana praktik open air cinema sebagai ruang dialog dan komunikasi warga di Desa Sumber. Metode penelitian yang digunakan adalah menggunakan pendekatan PRA (Partisipatory Research Appraisal). Pengambilan data dengan wawacara dan observasi dalam bentuk partisipatif. Kesimpulan dalam penelitian ini adalah bahwa eksebisi film dengan model open air cinema bisa menjadi medium dialog komunikasi warga. Produksi dan eksebisi film dapat mendukung relasi komunikasi yang demokratis.
\end{abstract}

Kata kunci : Produksi Film, Eksebisi Film, Open Air Cinema, Ruang Komunikasi

\begin{abstract}
Open air cinema is also called "layar tancap" is an exhibition style of film that plays in open space. Desa Sumber is in Magelang, Central Java, building a creative tourism village. The initial stage is exploring village potential as a commodity that will be offered as a tourist attraction. Film is considered to be a solution to answer these problems. Film as an art product was chosen as a medium for human empowerment, especially the medium to develop village potential. The purpose of this study was to find out the practice of open air cinema as a space for dialogue and communication in Sumber Village. The research method used is using the PRA (Participatory Research Appraisal) approach. Data retrieval by interview and participatory observation. The conclusion in this study is that film exhibition with an open air cinema model can be a medium of community communication. Film production and exhibition can support democratic communication relations.
\end{abstract}

Keyword : Film Production, Film Exhibition, Open Air Cinema, Communication Space

\section{PENDAHULUAN}

Desa Sumber adalah salah satu dari banyaknya desa dibawah administrasi Kabupaten Magelang, Provinsi Jawa Tengah, Indonesia. Sebagai sebuah kabupaten luas kabupaten Magelang adalah 1.085,73 $\mathrm{Km}^{2}$. Kabupaten Magelang membawahi 21 kecamatan dan 372 desa/ keluarahan (magelangkab.go.id, 2019).

Desa Sumber adalah salah satu desa 
yang berada di bawah administrasi Kecamatan Dukun, sekitar $10 \mathrm{Km}$ dari kecamatan Muntilan, Magelang. Luas Desa Sumber kurang lebih 100 hektar. Desa Sumber memiliki 12 pedukuhan dengan total 3537 jiwa. Untuk kelompok pekerjaan, dominan merupakan petani, yakni 38,5\%, diikuti pelajar/mahasiswa $17 \%$, tidak bekerja $13 \%$, karyawan swasta $8 \%$, buruh harian lepas $4 \%$ dan buruh tani/kebun $2 \%$ (desasumber.magelangkab.go.id, 2019). Jika dilihat dari sebaran pekerjaan, Desa Sumber didominasi oleh petani.

Desa Sumber sudah lama diproyeksikan menjadi desa wisata. Desa wisata adalah desa yang hidup mandiri dengan potensi yang dimiliknya dapat dijual sebagai atraksi daya tarik wisata tanpa melibatkan investor (Asyari, 2015). Potensi desa Sumber sebagai desa wisata sudah terlihat dari potensi sumber daya manusia dan sumber daya alamnya. Dari sisi alam, selain hamparan pertanian dan kesejukan alam, Desa Sumber mempunyai pemandangan yang indah dengan latar belakang Gunung Merapi. Jarak antara Desa Sumber dan puncak Gunung Merapi adalah $7 \mathrm{~km}$. Gunung Merapi berada di 4 wilayah kabupaten, yakni Magelang, Kabupaten Boyolali, dan Kabupaten Klaten, sedangkan di Yogyakarta terletak di Kabupaten Sleman. Gunung Merapi terletak pada posisi geografis $7^{\circ} 32.5^{\prime}$ Lintang Selatan dan $110^{\circ}$ 26,5' Bujur Timur (Triyoga, 2010). Desa Sumber berada di barat daya Gunung Merapi.

Selama ini Desa Sumber sudah memulai menjadi desa wisata edukasi. Desa wisata edukasi yang dikembangkan Desa Sumber adalah wisata yang menawarkan desa sebagai laboratorium alam yang bisa dieksplorasi oleh pelajar dalam proses pembelajaran. Terbukti diferensiasi ini mampu menarik beberapa sekolah berwisata di Desa Sumber.

Selain sumber daya alam, Desa Sumber juga mempunyai potensi sumber daya manusia, seperti aktifnya sanggar ketoprak "Santi Aji" yang dikelola secara mandiri oleh warga, komunitas Forum Anak yang rutin membuat event tahunan, serta komunitas film. Semuanya difasilitasi dan didukung oleh pihak pemerintahan desa.

Dalam sebuah diskusi dengan Eko Kalisno selaku Sekretaris Desa Sumber, film bisa menjadi alat promosi desanya. Caranya dengan memvideokan potensi desa dan kemudian dishare di Youtube atau bentuk sosial media lainnya. Ide ini merupakan hasil dari kegiatan pemuda Desa Sumber saat membuat workshop dengan LSM bernama PLAN pada tahun 2011. Namun sayangnya komunitas film ini vacum selama 5 tahun dan aktif kembali 5 tahun kemudian dengan kondisi seadanya. Eko mengharapkan kegiatan film bisa dimanfaatkan menjadi medium promosi.

Jika mengkaji sejarah, film pada awalnya hanya sebagai media refleksi realita. Ia dianggap sebagai sebuah teknologi yang merekam atau menangkap realita layaknya cermin. Film adalah sebuah potret dari masyarakat, dimana film itu dibuat. Film selalu merekam realitas yang tumbuh dan berkembang dalam masyarakat, dan kemudian memproyeksikan ke atas layar (Irawanto, 1999). Saat Augueste dan Louis Lumiere memproyeksikan karyanya di sebuah cafe di Perancis, film masih hanya sebatas menangkap gambar saja. Namun ditangan Augueste dan Louis Lumiere, lahir sebuah bentuk eksebisi film pertama di dunia (Sumarno, 1996).

Namun seiring berjalannya waktu, film mendapatkan tempat sebagai sebuah karya seni. Diawal tahun 1900-an muncul banyak seniman film seperti Eisenstein dari Rusia yang mengenalkan seni montage, atau Griffith yang mengenalkan bahasa film (Brodwell dan Thomson, 2003). Film pada akhirnya menetapkan diri sebagai sebuah karya seni yang kompleks. Banyak tokoh praktisi film layaknya Andre Bazin atau Ulrike Ottinger yang membuat teori tentang film menjadi semakin berbobot.

Film terus berkembang menjadi industri besar hingga sekarang ini. Hingga muncul pendekatan produksi-distribusi-eksebisi. Film berkembang menjadi lebih besar saat kemudian 3 lini bisnis film yakni produksi-distribsieksebisi disatukan dalam satu perusahaan yang kemudian disebut dengan integrasi vertikal. Sistem studio kemudian dibuat agar pemasaran menjadi lebih mudah (Brodwell dan Thomson, 2003).

Berbeda dengan masa lalu, di era media baru, teknologi film atau video semakin mudah didapatkan oleh masyarakat biasa. Media baru 
berakar pada digitalisasi dan virtualisasi (Lister, 2003). Karena medium video semakin praktis dan murah, maka sekarang ini masyarakat bisa dengan mudah ikut berkreasi dan berkreatifitas membuat karya film.

Lalu jika film sebagai sebuah karya seni, apakah film bisa menjadi medium menggali potensi desa?, atau sebagai medium komunikasi warga? Jika merujuk pada Sam Gregory dan Gillian Caldwell (2008) film atau video tidak hanya sebagai karya seni maupun karya seni industri, film bagi Gregory dan Caldwell adalah medium untuk perubahan sosial.

Lalu bagaimana posisi film atau video seperti yang digunakan oleh Desa Sumber sebagai medium penggali potensi desa? apakah film sebagai sebuah produk seni bisa ditunjukan sebagai medium perubahan sosial? Penelitian ini ingin menjawab bagaimana relasi produksi dan eksebisi dalam menemukan solusi permasalahan desa.

\section{LITERATUR REVIEW}

Film sebagai Media Konstruksi Realitas Sosial

Film adalah sebuah media yang mengandung unsur-unsur budaya yang mengkonstruksinya. Menggali dari pemikiran madzab Frankfurt media adalah sebagai sarana pembangunan budaya, lebih menekankan ide daripada barang material. Bagi madzab ini praktik dominasinya terletak pada manipulasi image media dan simbol-simbol untuk menguntungkan kepentingan kelas dominan (McQuail, 1987; Junaedi, 2007). Selaras dengan apa yang dikemukakan McQuail, Eriyanto melihat bahwa dalam hal ini media bukan sarana yang netral yang menampilkan kekuatan kelompok dalam masyarakat secara apa adanya, tetapi kelompok dan ideologi yang dominan itulah yang akan tampil dalam pemberitaan. Tony Benner seperti yang dikatakannya, media dipandang sebagai agen konstruksi sosial yang mendefinisikan realitas sesuai dengan kepentingannnya (Eriyanto, 2001).

Selain itu film juga bagian dari sebuah representasi. Lalu apa yang membedakan antara film sebagai konstruksi realitas dan film sebagai representasi? Konstruksi realitas lebih memandang bahwa semua manusia dipikirannya membawa stock of knowledge.
Stock of knwoledge itulah realitas mereka. Konstruksi realitas adalah sebuah fakta objetif yang dialami sebagai realitas yang alami. Sedangkan representasi adalah sebuah tanda yang tidak sama dengan realitas yang direpresentasikan sendiri yang berdasar pada referensinya (Noviani, 2002). Ada dua bentuk representasi, pertama representasi sebagai sebuah proses sosial representasi, dan yang kedua adalah produk representasi berupa makna.

Dalam konteks film sebagai alat pembedayaan masyarakat, peneliti memilih definisi flm sebagai konstruksi realitas sosial, dan tidak hanya sebatas repersentasi pemaknaan semata. Hal ini mengacu pada apa yang dikemukakan oleh Gregory dan Caldwell (2008), bahwa film sebagai karya visual sangat mudah menyampaikan informasi. Ia mampu menghadirkan "realita" yang menjadi kepentingan pembuat film. Video dalam menghadirkan pengaruh emosi yang kuat, sementara yang lain video bisa menjadi kendaraan membangun koalisi dengan kelompok lain yang bekerja dalam lingkup permasalahan yang sama.

Namun kritik peneliti pada apa yang dikemukakan oleh Gregory dan Caldwell adalah dalam hal video sebagai advokasi, pelaku permasalahan diposisikan sebagai objek. Gregory dan Caldwell menyebutnya sebagai sebuah kerja layaknya kerja jurnalisme. Pada konteks Desa Sumber, masyarakat akan lebih baik diposisikan sebagai subjek. Subjek yang dimaksud adalah warga memetakan permasalahan sendiri, mengelola masalahnya sendiri dan menyelesaikannya sendiri. Kebetulan film menjadi salah satu dari salah satu solusi yang dipilih.

Film tidak hanya sebagai alat perubahan dalam arti yang sempit, yang melibatkan unsur "orang luar" untuk menyelesaikan masalah atau menjelaskan permasalahan. Film pada satu hal sebagai cara melakukan empowerment dengan lebih mudah dalam permasalahan tertentu. empowerment menurut Carlzon dan Macauley (Wasistiono, 1998; Roesmidi dan Riyanti, 2006) yaitu membebaskan seseorang dari kendali yang kaku dan memberi orang tersebut kebebasan untuk bertanggungjawab terhadap ide-idenya, 
keputusan-keputusan dan tindakantindakannya. Mengacu pada definisi tersebut, maka dalam konteks film sebagai pembedayaan, posisi warga menjadi subjek yang harus mampu menyelesaikan permasalahan sendiri melalui ide-ide mereka.

Tiga lini film yang penting dalam memahami film, yakni produksi-distribusieksebisi (Brodwell dan Thomson, 2003). Eksebisi pada dasarnya adalah cara film ditontonkan kepada khalayak, dibagi menjadi 2, yakni theater, menggunakan layar bioskop, dan non-theater seperti di kampus, ruang pemutaran milik umum, perpustakaan. Dalam film non-theater biasanya menggunakan medium video. Dalam pemutaran non-theater biasanya yang diputar adalah film-film non komersil seperti dokumenter, eksperimental atau independen.

Distribusi sebagai muara dari bisnis film. Dari distributor diberikan ke jasa eksebisi untuk diputar ke khalayak. Selain itu, distributor juga menyediakan publikasi untuk mensukseskan sebuah film. Sedangkan produksi lebih pada konteks pra-produksipasca produksi.

\section{METODE PENELITIAN}

Penelitian ini menggunakan pendekatan participatory research appraisal (PRA). Pendekatan ini dipilih karena peneliti memilih untuk ikut berpartisipasi dengan masyarakat dengan menitikberatkan pada pemberdayaan masyarakat (empowerment). PRA adalah metode partisipatif (Adimihardja dan Hikmat, 2003). Penelitian dilakukan di Desa Sumber, Kecamatan Dukun, Kabupaten Magelang, Jawa Tengah, Indonesia. Waktu penelitian dilakukan selama 3 bulan dari bulan Januari 2019 hingga Maret 2019.

Adapun teknik pengumpulan data menggunakan pendekatan observasi partisipan. observasi merupakan metode pengumpulan data melalui indera (Mattews dan Ross, 2010; Herdiansah, 2013). Observasi partisipan bisa dilakukan dengan menjadi pendamping dalam pengelolan desa wisata kreatif. Bahwa dalam observasi, diperlukan posisi yang fungsional agar bisa menangkap fenomena (Machilng, 1974; Yin, 2006). Selain itu peneliti menggunakan wawancara openended. Wawancara open-ended adalah wawancara yang sifatnya cukup fleksibel. Peneliti mewawancarai responden tentang fakta-fakta suatu peristiwa, dan terbuka memberikan opini mereka terkait peristiwa yang ada. Pengambilan data yang selanjutnya adalah Focus Groups Discussion (FGD). FGD adalah instrumen penggali data yang berorientasi sosial (Herdiansah, 2013:139). Alasan memilih pengambilan data dengan teknik FGD adalah karena sumber bisa lebih terbuka, dikarenakan mendapatkan stimulus dari subjek yang lainnya.

\section{HASIL DAN PEMBAHASAN \\ Hasil Penelitian \\ Film sebagai medium Pemberdayaan}

Sementara ini film bagi kalangan pemuda Desa Sumber adalah sebatas sebagai sebuah produk seni bukan sebagai bagian dari "alat" komunikasi untuk menunjukan sesuatu. Dalam sebuah FGD pertama yang kami lakukan bersama dengan komunitas film Desa Sumber, ditemukan bahwa film bisa menjadi jembatan antara kreatifitas dan alat komunikasi bagi masyarakat Desa Sumber dalam menerjemahkan potensi desa.

Film dalam kasus di Desa Sumber telah memposisikan diri menjadi medium pemberdayaan. Film menjadi alat dari masyarakat dalam memetakan ide, permasalahan desa dan potensi desa. Film menjadi medium visual yang menjelaskan kepada masyarakat tentang kondisi permasalahan lingkungan desa ataupun solusi yang ingin dihadirkan kepada masyarakat. Selain itu film bisa menjadi humas bagi desa kepada masyarakat.

Film sebagai pemberdayaan terletak pada penggalian ide diawal sebelum pra produksi. Jika dalam konteks produk film sebagai sebuah karya seni, penggodokan ide diawal dianggap sebagai bagian dari proses kreatif, seperti pelibatan ide kreatif, marketing dan segment, kemudian disusul dengan pembuatan skenario atau sejenisnya dan kemudian masuk ke pra-produksi- pasca produksi, hal sedikit berbeda dengan film sebagai pemberdayaan. Film sebagai pemberdayaan meliputi; pemetaan masalah, ide, pesan yang ingin disampaikan kepada khalayak, dampak yang ingin dicapai, pelibatan subjek, mengandung unsur 
keterbukaan dan dialogis dalam proses menyampaikan masalah atau solusi. Setelah itu baru diteruskan pada pra produksi-produksipasca produksi. Berikut deskripsinya;

\section{Film sebagai Pemberdayaan}

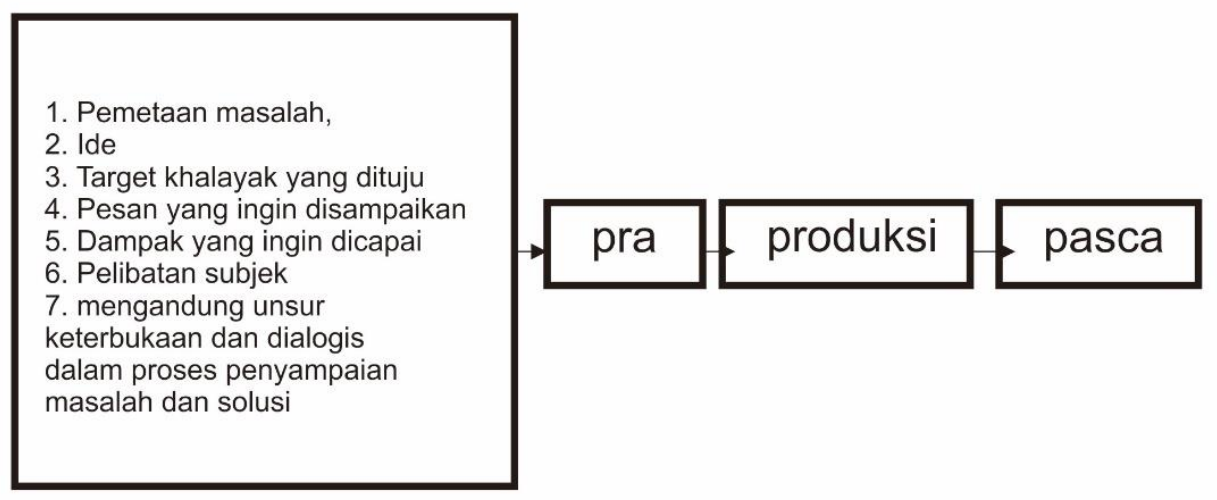

Gambar 1. Film sebagai Pemberdayaan

Sebelum masuk pada pra produksi, produksi dan pasca produksi, para pegiat film harus melakukan seperti apa yang dijelaskan di gambar 1, yakni pemetaan masalah, mencari ide, target khalayak yang dituju, pesan yang ingin disampaikan, dampak yang ingin dicapai, pelibatan subjek, dan yang terakhir adalah mengandung unsur keterbukaan dan dialogis dalam proses penyampaian masalah dan solusi. Pemetaan masalah adalah mengeksplorasi masalah-masalah apa saja yang penting untuk dipilih sebagai sebuah tema. Bisa jadi masalah, bisa jadi adalah potensi atau kelebihan yang dipetakan. Dalam kasus Desa Sumber kondisinya adalah memetakan potensi desa yang bisa dijadikan promosi desa maupun sebagai karya warga desa yang nantinya ditonton oleh warga desa.

Ide menyangkut pada kemasan film yang akan dibangun. Dalam bentuk film fiksi, dokumenter, film jurnalistik atau dalam bentuk kemasan video blog yang tujuannya akan dikemas dalam web series di Youtube atau bentuk sosial media lainnya.

Menetapkan khalayak yang dituju. Khalayak yang dituju akan mempengaruhi kemasan seperti apa film yang akan dibuat. Begitu juga dengan pesan yang akan disampaikan. Pesan yang sederhana ataukah pesan yang kompleks, pesan yang ideologis atau pesan yang sifatnya moral, pesan yang membangun motivasi atau pesan yang memberikan pertanyaan selanjutnya.

Film juga harus memikirkan dampak. Dampak apa yang ingin diharapkan. Misalnya dari film penonton menjadi peka terhadap lingkungan, film menimbulkan harapan atau motivasi, atau film tersebut dampaknya memancing pertanyaan-pertanyaan yang nantinya menjadi stimulus dalam sebuah diskusi.

Pelibatan subjek adalah hal yang penting. Pembuat video atau film adalah fasilitator, subjek adalah seseorang atau komunitas yang punya kepentingan memberikan statemen dalam film. Karena melalui film subjek ingin mengkomunikasikan sesuatu kepada khalayak. Menurut saya ini yang akan membedakan film dokumenter yang framing, narasi dan plot diarahkan oleh sutradara, sedangkan film dokumenter atau film jurnalistik dalam film sebagai pemberdayaan yang banyak melibatkan subjek dalam kerja filmnya.

Mengandung unsur keterbukaan dan dialogis dalam proses penyampaian permasalahan dan solusi. Film harus mampu mengandung unsur keterbukaan informasi dan mengandung unsur dialogis (dialektis) agar muncul stimulus dialog setelah film diputar. Dengan narasi film, masyarakat bisa cepat memahami permasalahan atau solusi yang nantinya bisa didiskusikan. 


\section{Eksebisi Film sebagai Manifestasi Komunikasi yang Demokratis}

Jika film sebagai sebuah produk visual bisa sebagai medium pemberdayaan, maka eksebisi bisa menjadi medium dialog dan komunikasi. Dalam konteks eksebisi, Desa Sumber membuat event pemutaran yang mereka sebut sebagai simulasi "Ndeso Film Festival". Disebut simulasi karena event 2 maret 2019 tersebut adalah bentuk ujicoba sebelum event sebenarnya diadakan. Desa Sumber akan membuat event tahunan dengan julukan Ndeso Film Festival (NFF). Ndeso diambil dari kata desa yang merujuk bahwa festival film yang akan diadakan adalah festival film tentang desa.

Event ini menggunakan pendekatan open air cinema. Open air cinema adalah layar tancapan (Subangun, 2018). Open air cinema sering dipahami orang Indonesia dengan nama layar tancap. Layarnya dipasang di ruang terbuka seperti lapangan agar banyak orang menonton.

Menarik dari open air cinema adalah bukan hanya pada film yang disuguhkan, namun juga peristiwa event tersebut yang juga menarik. Open air cinema Desa Sumber terbuka umum. Segala umur boleh hadir dan menonton. Film yang dipilihnya pun film-film lokal yang dekat dengan masyarakat Desa Sumber. Setelah film selesai, dibuka sesi tanya jawab dan diskusi tekait film tersebut. Masyarakat bebas menanyakan apapun tentang film tersebut, atau memberikan komentar terhadap film tersebut.

Sesi menonton secara terbuka dan egaliter, serta sesi diskusi yang mengalir menjadi ajang komunikasi yang setara dan demokratis. Event tersebut menjadi milik warga untuk berkumpul, memberikan pendapat dan memberikan respon tentang banyak hal.

Berbeda dengan eksebisi film dalam konteks yang normatif. Dalam ruang lingkup pembedayaan masyarakat, eksebisi bisa dikemas dalam ruang komunitas yang partisipatif dan egaliter seperti apa yang dilakukan di Desa Sumber dengan format open air cinema atau layar tancap.

Kami melihat ada relasi menarik antara produksi film dan eksebisi dalam semangat pembedayaan masyarakat. Kami menemukan bahwa film menjadi medium pemberdayaan dan eksebisi sebagai medium "forum warga". Maka dalam penelitian ini kami menemukan dua pilar utama film sebagai pemberdayaan dalam sebuah relasi hubungan. Berikut adalah gambaran yang bisa dijelaskan melalui model ;

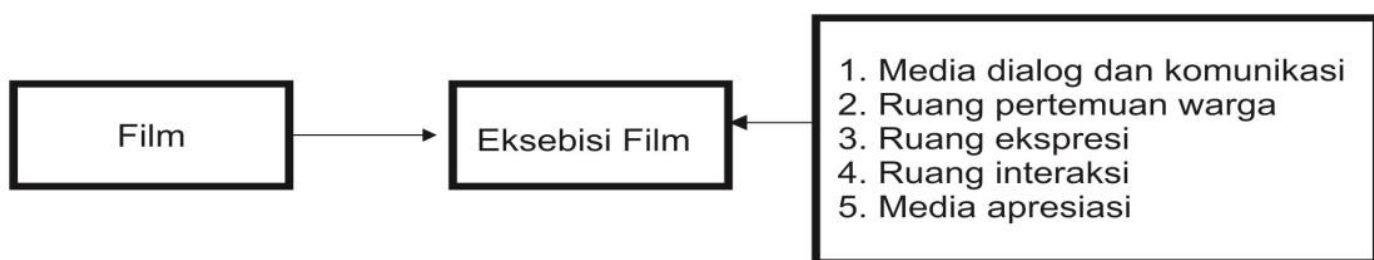

Gambar 2. Model relasi produksi dan eksebisi pada open air cinema di Desa Sumber.

\section{Pembahasan}

Diskusi dengan membentuk FGD adalah langkah awal dalam melihat bagaimana pemuda Desa Sumber dalam memahami film, serta bagaimana pemuda Desa Sumber dalam memahami permasalahan dan potensi desa dalam medium film. Diskusi ini penting untuk menentukan langkah selanjutnya tentang bagaimana medium film digunakan 


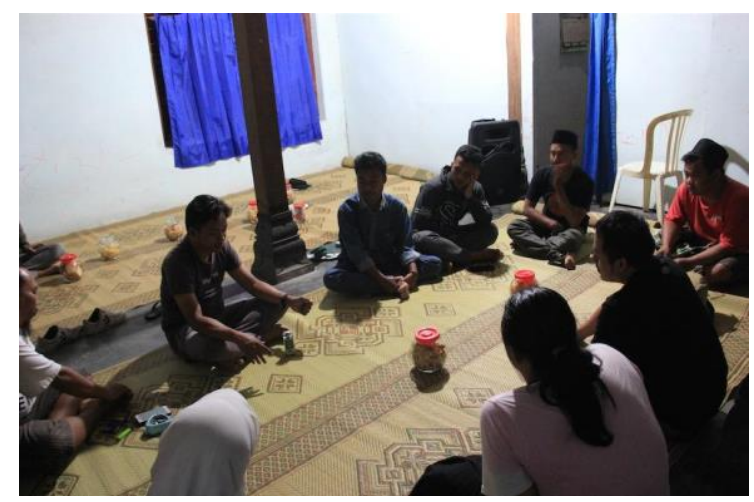

(a)

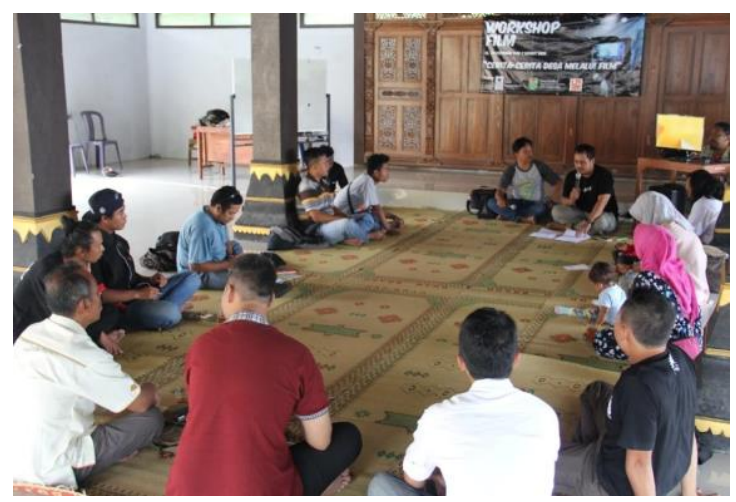

(b)

Gambar 3. (a) FGD pertama (16 Februari 2019) dilakukan satu minggu sebelum dilaksanakan FGD kedua yang melibatkan elemen masyarakat Desa Sumber yang lebih besar, hanya melibatkan pegiat film Desa Sumber. (b) FGD kedua (24 Ferbuari 2019) melibatkan elemen masyarakat lebih banyak, seperti POKDARWIS (Kelompok Sadar Wisata) Desa Sumber, Forum Anak, serta elemen masyarakat lainnya.

Dalam FGD kedua, kami melibatkan pembicara dari luar Desa untuk membagikan pengalaman terkait film dan pengelolaan komunitas. Diundang adalah Bowo Leksono dari Direktur Festival Film Purbalingga (FFP),
Insan Indah Pribadi dari Komunitas Film Sangkanparan Cilacap, Mart Widarto dari aktifis pembedayaan desa, serta Citra Dewi Utami dari ISI Surakarta.

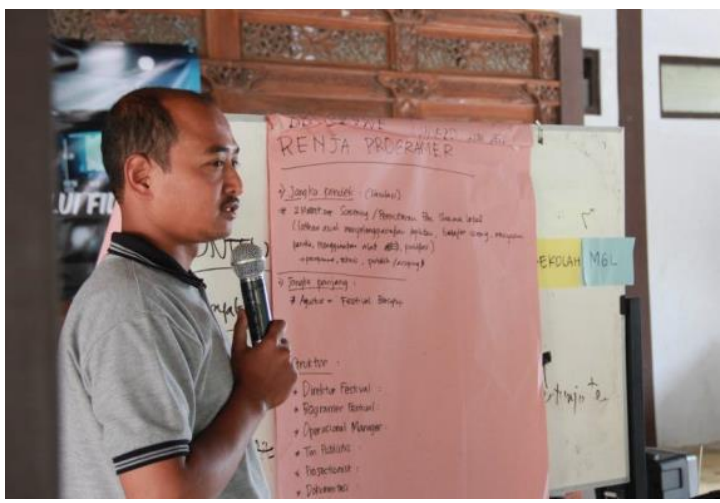

(a)

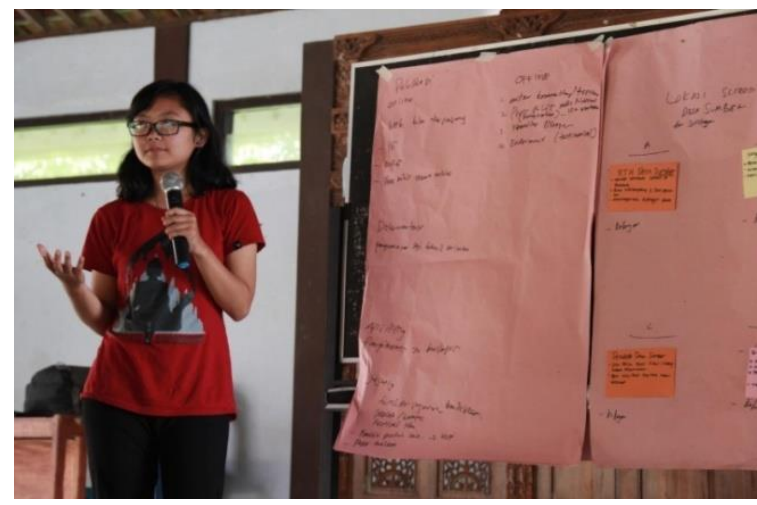

(b)

Gambar 4. (a) Eko Kalisno struktural Kelurahan selaku Carik, juga ikut aktif dalam acara FGD. (b) Santi (23th) salah satu peserta mempresentasikan rencana tindak lanjut hasil FGD Pengelolaan Festival Film berbasis komunitas desa

Peran pihak Kelurahan Desa Sumber cukup tinggi. Hal ini terlihat dari keterlibatan langsung Eko Kalisno sebagai Carik Desa

\section{Dialog Egaliter melalui Ruang-ruang Film}

Ruang film berupa film itu sendiri dan ruang eksebisi adalah ruang-ruang dialog yang egaliter. Dalam film pemberdayaan, film menyediakan problem dan solusi yang menjadi
Sumber dalam semua persiapan event eksebisi hingga berlangsungnya event eksebisi film.

motivasi ataupun tantangan bagi masyarakat. Eksebisi film dalam ruang open air cinema bisa menjadi medium dialog yang egaliter antara penguasa dan warga, atau antar warga dan warga. 
Film yang kemudian disebut sebagai film pemberdayaan membuka kran komunikasi yang terbuka. Seperti menurut Habermas bahwa interaksi adalah wujud dari humanisasi (Agger, 2003). Wujud demokratisasi yang emansipatoris terwujud pada bentuk eksebisi film. Habermas mengatakan bahwa sebuah masyarakat yang emansipatoris bebas dari dominasi, dan setiap orang memiliki kesempatan yang sama dalam membuat keputusan. Syarat yang penting dalam kondisi ini adalah lingkup publik yang kuat (Hardiman, 1990). Bagi Habermas komunikasi menjadi peran yang penting dalam membangun masyarakat yang emansipasif. Berangkat dari komunikasi sebagai unsur utama, film pembedayaan menjadi salah satu upaya dalam membangun komunikasi. Dengan kompetensi yang baik, film bisa menyuarakan permasalahan, motivasi maupun solusi bagi masyarakat.

Selain itu ruang publik dibutuhkan untuk mempraktikan masyarakat emansipatif tersebut. Eksebisi menjadi media dan ruang bagi masyarakat untuk saling berinterkasi satu sama lain dan saling memberikan kesempatan memberikan pendapat.

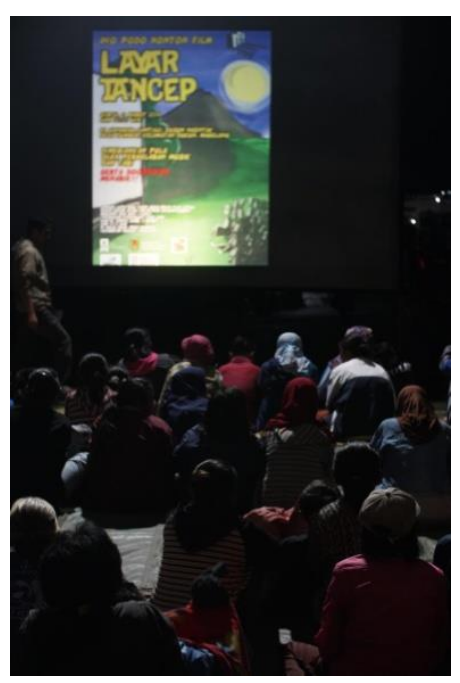

(a)

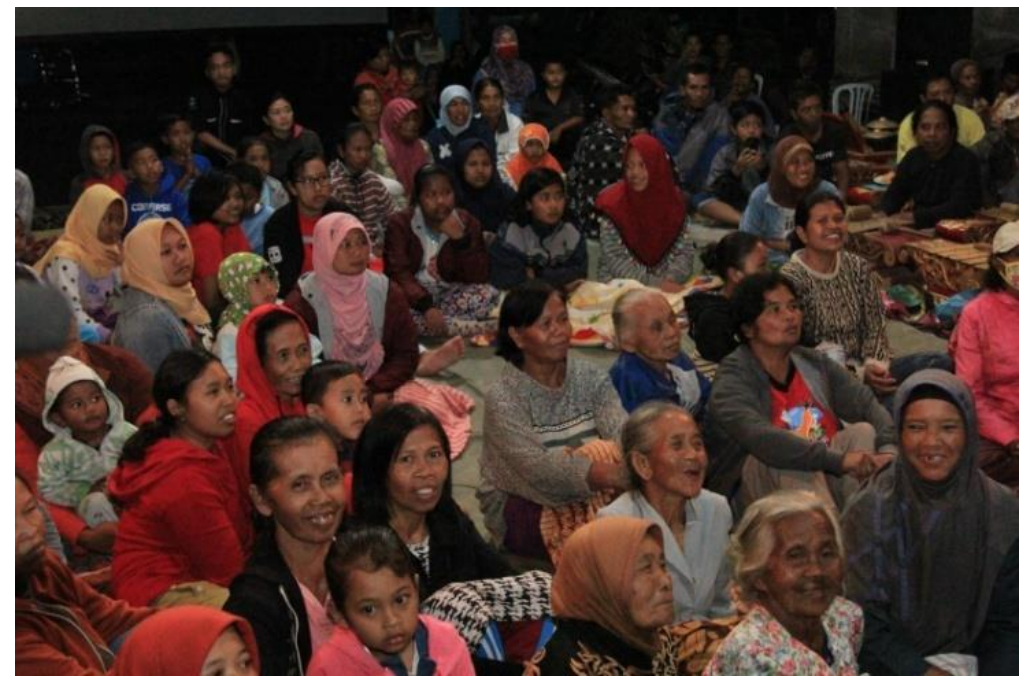

(b)

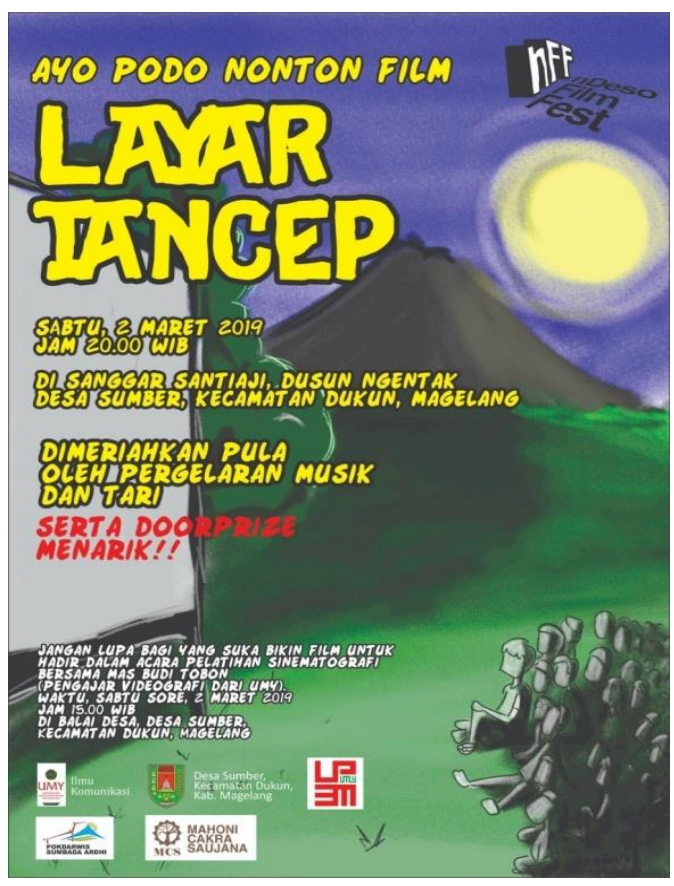

(c)

Gambar 5. (a) dan (b), kondisi eksebisi film di Desa Sumber. (c) poster acara layar tancap. 
Habermas meyakini bahwa berbicara diperlukan untuk menciptakan komunikasi yang normal dan produktif. Seperti menurut Atie Rachmiatie (2007) situasi pembicaraan di masyarakat harus dimodelkan sebagai berikut;

a. Situasi pembicaraan yang ideal menuntut kebebasan berbicara, tidak boleh ada kekangan terhadap apa yang bisa diungkapkan.

b. Semua individu harus memiliki akses yang sama untuk berbicara.

c. Norma-norma, kewajibankewajiban masyarakat tidak bersisi satu, tetapi terdistribusi secara sama pada semua lapisan masyarakat.

Film pembedayaan dan eksebisi open air cinema Desa Sumber mencoba menerapkan situasi komunikasi yang ideal, dengan tidak melakukan intervensi. Hal ini dilihat dari cara eksebisi yang terbuka dan membuka komentar terkait dengan film yang diputar. Selain itu warga juga diberikan keleluasaan dalam mengekspresikan ide dan kreatifitas pada event tersebut. dari event eksebisi ini masyarakat bisa saling berinteraksi dan menjadikan ruang eksebisi sebagai forum warga. Kondisi komunikasi yang egaliter penting sebagai bagian dari praktik demokrasi partisipatoris.

\section{Film Pembedayaan Tanpa Distribusi}

Distrubusi dalam indutri film adalah elemen yang paling banyak mendapatkan keuntungan (Brodwell dan Thomson, 2003). Distribusi adalah elemen yang mempunyai hak kemana film akan dieksebisikan. Kartel distribusi film inilah yang membuat pemasaran film menjadi sulit tertembus. Lihat saja bagimana kuatnya AOL Time Warner, Sony, Disney, Universal yang mampu menguasai distribusi film di seluruh dunia, berbanding dengan kondisi film di Indonesia yang masih terus berkutat dengan bermodalan dan regulasi. Bagi kalangan pegiat film yang tidak masuk dalam kartel distribusi film cenderung tidak akan mudah bergerak selain membangun jaringan distribusinya sendiri. Tentunya pilihan membangun distribusinya sendiri akan menghadapi kondisi yang tak kalah sulitnya.
Sudah banyak alternatif terhadap kartel distribusi film, seperti munculnya Milestones film, Miramax, Sony Pictures Classic, dan Warner Independent Pictures, namun tetap saja sebagian dari agen distribusi tersebut masih berafiliasi ke industri besar.

Namun di era teknologi media baru, film tidak lagi milik industri besar, begitu juga dengan distribusi dan eksebisinya. Film bisa diproduksi dengan alat yang terjangkau, lalu menayangkannya dalam ruang-ruang alternatif dengan diskusi didalamnya. Kembali ke Desa Sumber, produksi film yang diproduksi oleh pegiat film Desa Sumber adalah bagian dari sebuah relasi dengan eksebisi yang dibuat. Melalui Ndeso Film Festival pegiat film Desa Sumber membuat film untuk nantinya dieksebisikan pada event tersebut. Mereka paham dengan cara menyesuaikan ide, tema, pesan yang akan disampaikan dalam film.

Saat riset dilakukan, pegiat film Desa Sumber masih dalam proses pemahaman dalam membuat film dalam ruang lingkup pembedayaan. Karya-karya film sebelumnya masih belum mewakili kegelisahan, permasalahan atau potensi Desa Sumber. Berangkat dari pemahaman tersebut, setelah event eksebisi simulasi NFF, pegiat film Desa Sumber sudah siap memproduksi film berjudul "Ledhek Bariem". Film ini merupakan bentuk kerjasama dengan sanggar Santiaji, sebuah sanggar ketoprak di lingkungan Desa Sumber. Kerjasama ini adalah bagian dari cara masyarakat berinteraksi dan berdialog dalam menggarap potensi desa. Film ini akan dirilis pada eksebisi Ndeso Film Festival, dan selanjutnya akan ditayangkan dalam event yang lain.

Sebagai film independent, seringkali film dipasarkan sendiri. Distribusi tidak secara langsung memegang peranan. Film pemberdayaan yang mencakup dampak komunikasi tentu saja memperlukan kondisi eksebisi yang khusus dan alternatif.

\section{KESIMPULAN}

Dari hasil temuan penelitian, dan sebagai bagian dari kontribusi riset terhadap perkembangan studi filmologi dan komunikasi pembangunan, maka kesimpulannya adalah sebagai berikut; 
Pertama, bahwa film bukan hanya sebagai medium refleksi, namun juga sebagai medium konstruksi realitas sosial. film bisa menghasilkan realitas-realitas yang dihadirkan melalui stock of knowledge penontonnya. Film pembedayaan memanfaatkan konstruksi realitas tersebut sebagai cara memetakan masalah, membangun ide, menentukan segment, membuat pesan, dampak yang diharapkan, melibatkan subjek, dan membuat film dalam ruang dialog yang terbuka. Kedua, eksebisi film dengan pendekatan open air cinema bisa membangun stimulus relasi antara film yang emansipatoris dengan event eksebisi yang melibatkan komunikasi interaksi yang egaliter, terbuka dan demokratis.

Saran untuk penelitian selanjutnya, perlu pengembangan tentang bagaimana konsep distribusi film yang mengedepankan film perbedayaan masyarakat. Agar upaya membuat konsep produksi-distribusi-eksebisi dalam film pembedayaan bisa terjawab secara sempurna.

\section{DAFTAR PUSTAKA}

Adimihardja, Kusnaka, Prof. Dr., dan Hikmat, Harry, Dr, Ir, M.Si, (2003), Participatory Research Appraisal: dalam Pelaksanaan Pengabdian kepada Masyarakat, Humaniora, Bandung.

Agger, Ben, (2003), Teori Sosial Kritis, (diterjemahkan oleh Nurhadi), Yogyakarta, Kreasi Wacana.

Asyari, Hasbullah, (2015), Buku Pegangan

Desa Wisata: Materi Bimbingan Teknis untuk Desa Wisata, Pustaka Zeedny, Yogyakarta.

Boordweel, David., dan Thomson, Kristin (2003), Film Art: An Introduction, McGraw-Hill Companies, USA

Eriyanto, (2001), Analisis Wacana, Yogyakarta:LKiS.

Gregory, Sam dan Caldwell, Gillian, (2008), Video for Change, Insist Press, Yogyakarta
Hardiman, Frascisco Budi, (1990), Kritik Ideologi: Pertautan Pengetahuan dan Kepentingan, Yogyakarta, Kanisius

Herdiansyah, Haris, (2013), Wawancara, Observasi dan Focus Groups, Rajawali Press, Jakarta.

http://desasumber.magelangkab.go.id/first/kat egori/2, 2019

http://magelangkab.go.id/home/detail/kondisigeografis/1809, 2019

Irawanto, Budi, (1999) Film, Ideologi, dan Militer: Hegemoni Militer dalam Sinema Indonesia, Yogyakarta: Media Pressindo.

Junaedi, Fajar, (2007), Komunikasi Massa: Pengantar Teoritis, Yogyakarta, Penerbit Santusta.

Lister, Martin et.al, (2003), New Media: A Critical Introduction, London and New York, Routlege

Noviani, Ratna, (2002), Jalan Tengah Memahami Iklan, Yogyakarta: Pustaka Pelajar.

Rachmiatie, Atie Dr., M.Si, (2007) Radio Komunitas; Eskalasi Demokratisasi Komunikasi, Simbiosa Rekatama Media, Bandung.

Roesmidi, Drs, M.M dan Risyanti, Riza, Dra (2006), Pemberdayaan Masyarakat, Alqaprint, Sumedang.

Subangun, 2019, https://jafffilmfest.org/open-air-cinema/

Sumarno, Marselli, Dasar-dasar Apresiasi Film, 1996, Jakarta: Grasindo.

Triyoga, Lucas Sasongko, (2010), Merapi dan Orang Jawa: Persepsi dan Kepercayaannya, Jakarta, Indonesia, Grasindo Press. 
Yin, Robert, k, (2006), Studi Kasus, Desain dan Metode, (Penerjemah M. Djauzi Mudzakir), Rajawali Press, Jakarta. 